Ekonomia - Wroclaw Economic Review 24/3 (2018)

Acta Universitatis Wratislaviensis

No 3881

DOI: 10.19195/2084-4093.24.3.5

\author{
Agnieszka Dejnaka \\ ORCID: 0000-0001-6222-3187 \\ Wyższa Szkoła Bankowa we Wrocławiu \\ dejnaka@post.pl
}

\title{
Aplikacje mobilne typu fit - planowanie posiłków i dieta pod kontrolą technologii
}

\author{
Artykuł nadesłany: 5 września 2018 r.; artykuł zaakceptowany: 10 września 2018 r. \\ JEL Classification: I12, I14, M3
}

Keywords: mobile applications, diet, calorie calculator, product composition, technology

Abstract

Fitness mobile applications: Meal planning and diet under technological control

More and more people in Poland begin to check in detail what products they buy and what they consume every day. Some of these people are on a diet that reduces weight or try to match/plan meals to meet the needs of their body (e.g. a sports training plan). Mobile applications come to their aid, as they facilitate the above processes related to meal planning and diet. The aim of the article is to present the results of qualitative research and critical analysis of mobile applications available on the market in the field of meal planning, introducing a reduction diet and maintaining it. The article also attempts to answer the following questions: What is the assessment and expectations for fitness mobile applications by users? Are meal planning and diets under the control of technology a trend or a necessity?

\section{Wstęp}

Coraz więcej osób w Polsce zaczyna szczegółowo sprawdzać, jakie produkty kupuje i jakie spożywa na co dzień. Część z tych osób jest na diecie redukującej wagę lub stara się dobierać/planować posiłki do potrzeb swojego organizmu (na przykład planu treningów sportowych). Co jest tego przyczyną? Stale nagłaśniane są informacje o szkodliwości wybranych produktów, zbyt dużej ilości cukru, które spożywamy w codziennych posiłkach, oraz moda na „bycie fit”. Jednym z rozwiązań, aby odpowiednio się odżywiać i dobrać zakres spożywanych posiłków do potrzeb organizmu jest wizyta u dietetyka. Jednakże z pomocą przychodzą 
także aplikacje mobilne, które pozwalają odciążyć użytkownika od żmudnego liczenia kalorii, dobierania odpowiedniej ilości białka, węglowodanów i tłuszczów w codziennych posiłkach. Co więcej, aplikacje mobilne pozwalają na skanowanie kodów produktów i sprawdzanie jego składu i kaloryczności, są stale przy użytkowniku oraz alarmują, gdy przekroczone zostają wskazane limity spożytych kalorii lub produkt z grupy „nie odpowiednich żywnościowo”.

\section{Aplikacje mobilne}

Jednym z czynników wpływających na rozwój współczesnej gospodarki jest wprowadzenie nowoczesnych technologii informacyjnych, w tym technologii mobilnych (Sznajder, 2014, s. 13). Mobilność w ogólnym ujęciu znaczy przenośność, możliwość korzystania z wybranych urządzeń w dogodnym miejscu i czasie.

Według I. Pawełoszek-Korek technologia mobilna to dziedzina zajmująca się wytwarzaniem produktów mobilnych, czyli takich, które mogą być używane w ruchu. Do charakterystycznych cech technologii mobilnej kreujących wartość dodaną dla użytkownika można zaliczyć (Pawełoszek-Korek, 2009, s. 30):

- wszechobecność (użytkownicy mają możliwość otrzymywania aktualnej informacji i przeprowadzania transakcji w czasie rzeczywistym),

- personalizacja (aplikacje powinny być dostosowane do potrzeb użytkownika, istotna jest zatem relewancja treści),

- elastyczność (użytkownicy mają możliwość włączania się w działania w czasie dla nich odpowiednim),

- lokalizacja (użytkownicy mają dostęp do lokalnych serwisów informacyjnych).

Aplikacja mobilna to inaczej program użytkowy zaprojektowany na urządzenia przenośne (mobilne), definiowane jako urządzenie elektroniczne pozwalające na przetwarzanie, odbieranie oraz wysyłanie danych bez konieczności utrzymywania przewodowego połączenia z siecią. Urządzenie mobilne może być przenoszone przez użytkownika bez konieczności angażowania dodatkowych środków (Frąckiewicz, 2006, s. 45-48).

Aplikacje mobilne coraz lepiej sprawdzają się w promocji i pozyskaniu klienta. Kluczowym zadaniem narzędzi wspomagających zakup i sprzedaż jest uproszczenie poszczególnych procesów związanych z e-handlem w aplikacjach mobilnych. Klienci oraz firmy bardzo często wykorzystują te same narzędzia do zupełnie innych celów; przedsiębiorstwa handlowe, wdrażając konkretny instrument, weryfikują jego skuteczność w stosunku do uzyskanych korzyści. Natomiast docelowym efektem stosowania różnego rodzaju narzędzi przez indywidualnego klienta jest zakup satysfakcjonujący dobra bądź usługi, spełniający wcześniejsze wymagania. 
Obecnie na rynku występuje bardzo duża liczba aplikacji na urządzenia mobilne. Każda branża wypuszcza na rynek własne programy. Mają one na celu zarówno zabawę, naukę, jak i pracę. Trudno jest jednoznacznie wyszczególnić rodzaje aplikacji mobilnych. Ze względu na zastosowanie aplikacje można podzielić na:

— aplikacje komunikatywne — społecznościowe;

— aplikacje biznesowe, w tym bankowe (płatnicze);

— aplikacje m-health;

— aplikacje nawigacyjne i lokalizacyjne;

— aplikacje rozrywkowe, na przykład gry;

- aplikacje do robienia zakupów;

— aplikacje do obróbki i zarządzania zdjęciami i wideo;

- aplikacje muzyczne itp.

Aplikacje mobilne m-health szybko znalazły szerokie zastosowanie w ochronie zdrowia. Aplikacje m-health dzielimy na:

- aplikacje medyczne pozwalające kontrolować stan zdrowia użytkowników oraz przypominające o przyjmowaniu leków lub badaniach okresowych;

— aplikacje sportowe pokazujące na przykład jaki dystans i w jakim czasie przebiegł użytkownik, ile kalorii spalił lub odczyt pulsu. Przykładowe aplikacje to Endomondo lub FatSecret ${ }^{1}$;

— aplikacje profilaktyki zdrowia pozwalające użytkownikowi między innymi zdobyć wiedzę na temat zdrowego odżywiania się, snu itp.;

- aplikacje typu fitness, mierzące poziom wysiłku fizycznego, motywujące do uprawiania sportu albo podpowiadające, jak utrzymać dobrą formę i zrzucić zbędne kilogramy.

W obszarze aplikacji typu fitness wyróżniamy aplikacje do liczenia kalorii i ustalania diety (redukcyjnej, niskotłuszczowej itp.). Często są one powiązane z planem treningowym (na przykład aplikacja Endomondo ${ }^{2}$ ) i wagą pomiaru składu ciała (na przykład waga z aplikacją MiFit ${ }^{3}$ ).

\section{Aplikacje mobilne do planowania posiłków i wprowadzania diety - ocena i analiza krytyczna}

W trakcie dokonywania oceny aplikacji mobilnych można kierować się różnymi kryteriami, na przykład oceną interfejsu oraz funkcjonalności. Ch. Mureta podaje

\footnotetext{
${ }^{1}$ Aplikacje sportowe, http://marketingbusiness.p1/technologie/wspolczesne-aplikacje-sportowe/hur_qgey (dostęp: 17.08.2018).

2 Więcej na temat funkcjonalności Endomondo, http://www.komputerswiat.pl/poradniki/smartfony-i-tablety/aplikacje/2017/06/endomondo-sports-tracker.aspx (dostęp: 17.08.2018).

3 Więcej na temat aplikacji MiFit, https://play.google.com/store/apps/details?id=com.xiaomi. hm.health\&hl=pl (dostęp: 17.08.2018).
} 
również takie kryteria, jak (Mureta, 2013, s. 83): rozrywka, intuicja, zaangażowanie, uzależnienie, wartości, wielokulturowość, audiowizualność oraz wirtualność. W trakcie przeprowadzania oceny należy jednak zwrócić uwagę na charakter funkcji realizowanych przez aplikację (czy ma ona charakter rozrywkowy, czy produktowy). Aplikacje do liczenia kalorii powinny być głównie funkcjonalne oraz motywować do prawidłowego odżywiania się i wprowadzania przez użytkownika odpowiednich nawyków żywnościowych.

Analiza wybranych aplikacji wykonana została z uwzględnieniem następujących kryteriów:

— funkcjonalności i intuicyjności - gdyż skomplikowana obsługa i trudności z wprowadzaniem/odczytywaniem danych zniechęca użytkowników,

— możliwości łatwego skanowania/wprowadzania dań oraz produktów oraz/ lub wielkość bazy produktów spożywczych,

— dopasowania do potrzeb użytkownika — założonych celów żywnościowych, określenia diety, aktywności fizycznych, możliwości finansowych związanych z zakupem produktów,

— monitorowanie spożytych produktów/kalorii/składników odżywczych,

- alerty informacyjne,

— estetyka interfejsu.

\section{Procedura badawcza}

Aplikacje mobilne przez trzy miesiące testowało 40 osób. Badanie odbywało się w miesiącach kwiecień-czerwiec 2018 roku. Charakterystyka respondentów: osoby w wieku 25-45 lat, uprawiające sport trzy razy w tygodniu, ich celem jest przejście na dietę redukującą lub dietę budującą masę mięśniową. Osoby korzystające wcześniej z dietetyka tradycyjnego, chcące przejść na dietę mobilną.

Pytania badawcze:

1. Jaka jest ocena i oczekiwania wobec aplikacji mobilnych fit przez użytkowników?

2. Czy planowanie posiłków oraz dieta pod kontrolą technologii to trend, czy konieczność?

Analizie poddano następujące aplikacje:

- Fitatu,

- FatSecret,

- Kcalmar - dieta i przepisy,

- Kalkulator Kalorii,

- MyFitnessPal.

Przebieg badania: równoczesne korzystanie z pięciu aplikacji mobilnych fit przez trzy miesięcy z zapisywaniem danych żywnościowych. 


\subsection{Wnioski z badania - analiza krytyczna}

\section{Fitatu 4}

Fitatu to intuicyjna aplikacja mobilna do liczenia kalorii i określania ilości składników odżywczych spożywanych w ciągu dnia (rysunek1).

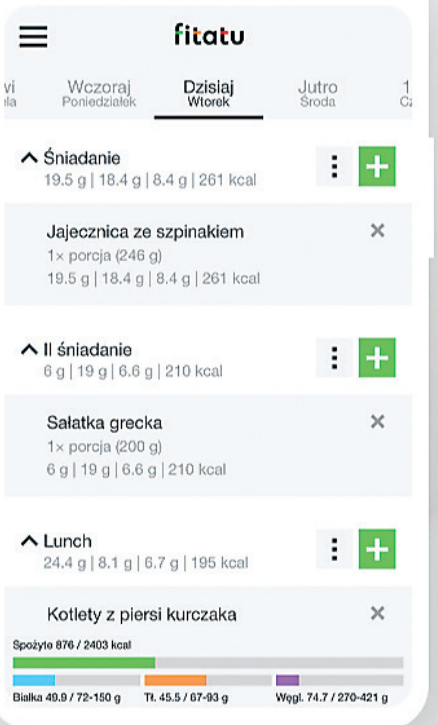

Rysunek 1. Aplikacja mobilna Fitatu

Źródło: http://pl-pl.fitatu.com/.

Wyniki badania wskazały:

1. zalety:

- aplikacja pozwala na określenie celu użytkownika po uzupełnieniu konta danymi (płci, wieku, wzrostu, masy i chęci osiągnięcia docelowej masy ciała), poziomu ruchu bez treningów (bardzo niski, niski, średni, wysoki) i poziom aktywności treningowej,

— precyzyjnie zorganizowany podział ilości posiłków,

— prosty i intuicyjny interfejs,

— możliwość skanowania produktów — kod kreskowy lub wprowadzania produktów ręcznie,

— aplikacja wskazuje na ilość zjedzonego białka, tłuszczów i węglowodanów, a także witamin i minerałów w posiłkach,

— wskazuje również spożyte kalorie i ile pozostało dziennego zapotrzebowania;

${ }^{4}$ Fitatu, http://pl-pl.fitatu.com/ (dostęp: 17.08.2018). 
2. wady: tości,

— brak niektórych produktów i konieczność ręcznego wprowadzania war-

— brak strony WWW,

— mało zaawansowane funkcje dotyczące na przykład planowania dań przepisy,

— brak zdjęć.

\section{FatSecret ${ }^{5}$}

FatSecret to atrakcyjna wizualnie aplikacja do liczenia kalorii oraz planowania posiłków (rysunek 2).

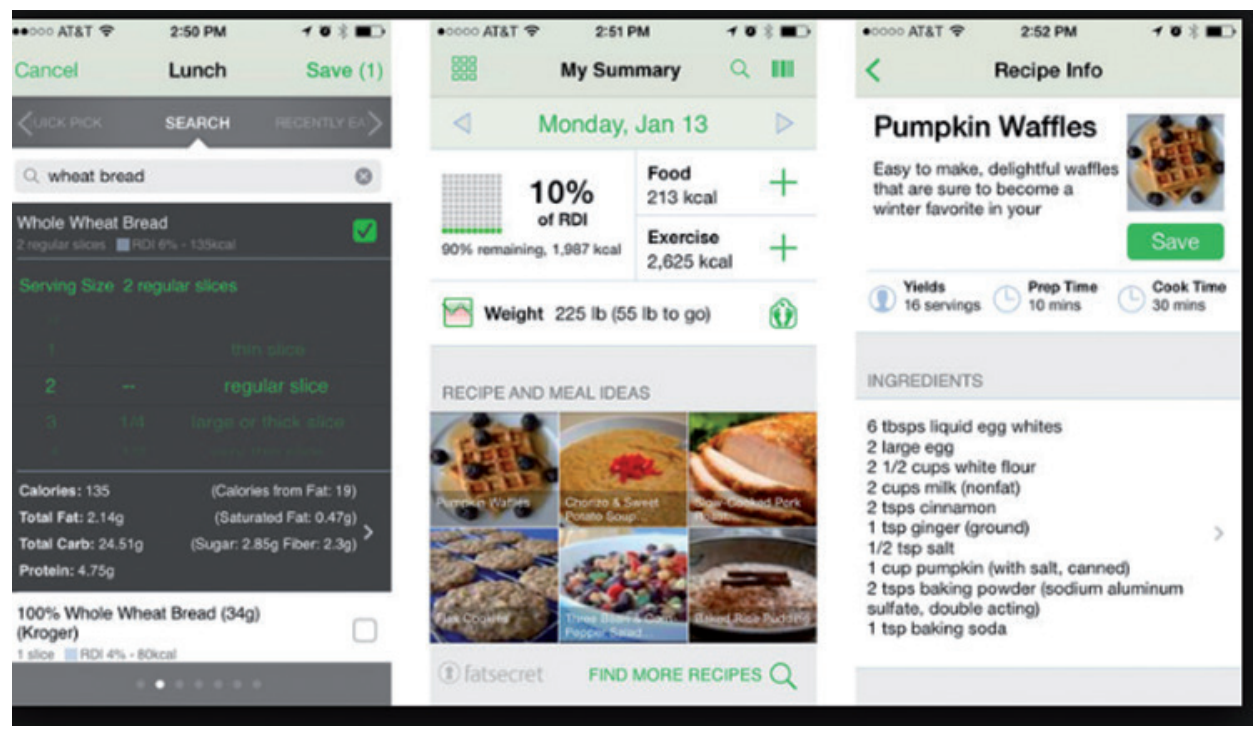

Rysunek 2. FatSecret

Źródło: https://www.fatsecret.pl/.

Wyniki badania wskazały:

1. zalety:

- aplikacja pozwala na określenie celu użytkownika po uzupełnieniu konta danymi (płci, wieku, wzrostu, masy i chęci osiągnięcia docelowej masy ciała), typu prowadzonej aktywności (siedzący, mało aktywny, aktywny, bardzo aktywny), aktualnej wagi i wzrostu,

— atrakcyjny i intuicyjny interfejs,

- planowanie podziału posiłków,

— możliwość skanowania produktów (kod kreskowy) lub wprowadzania produktów ręcznie,

5 FatSecret, https://www.fatsecret.pl/ (dostęp: 17.08.2018). 
— aplikacja wskazuje na ilość zjedzonego białka, tłuszczów i węglowodanów, a także witamin i minerałów w posiłkach. Poza kaloriami można sprawdzić ilość makroelementów oraz węglowodanów, białka, błonnika, cukru, tłuszczu, cholesterolu, sodu i potasu,

— wskazuje również spożyte kalorie i ile pozostało dziennego zapotrzebowania - w bardzo intuicyjny, obrazowy sposób,

- aplikacja zawiera także dział prostych przepisów oraz raport całościowych postępów w żywieniu,

- ma stronę WWW;

2. wady:

— brak możliwości wpisania kolacji.

\section{MyFitnessPal 6}

MyFitnessPal to jedna z popularniejszych aplikacji i stron z możliwością prowadzenia dziennika żywieniowego. Można z niej korzystać zarówno z telefonu za pomocą aplikacji, jak i z komputera czy tabletu za pomocą strony internetowej (rysunek 3).

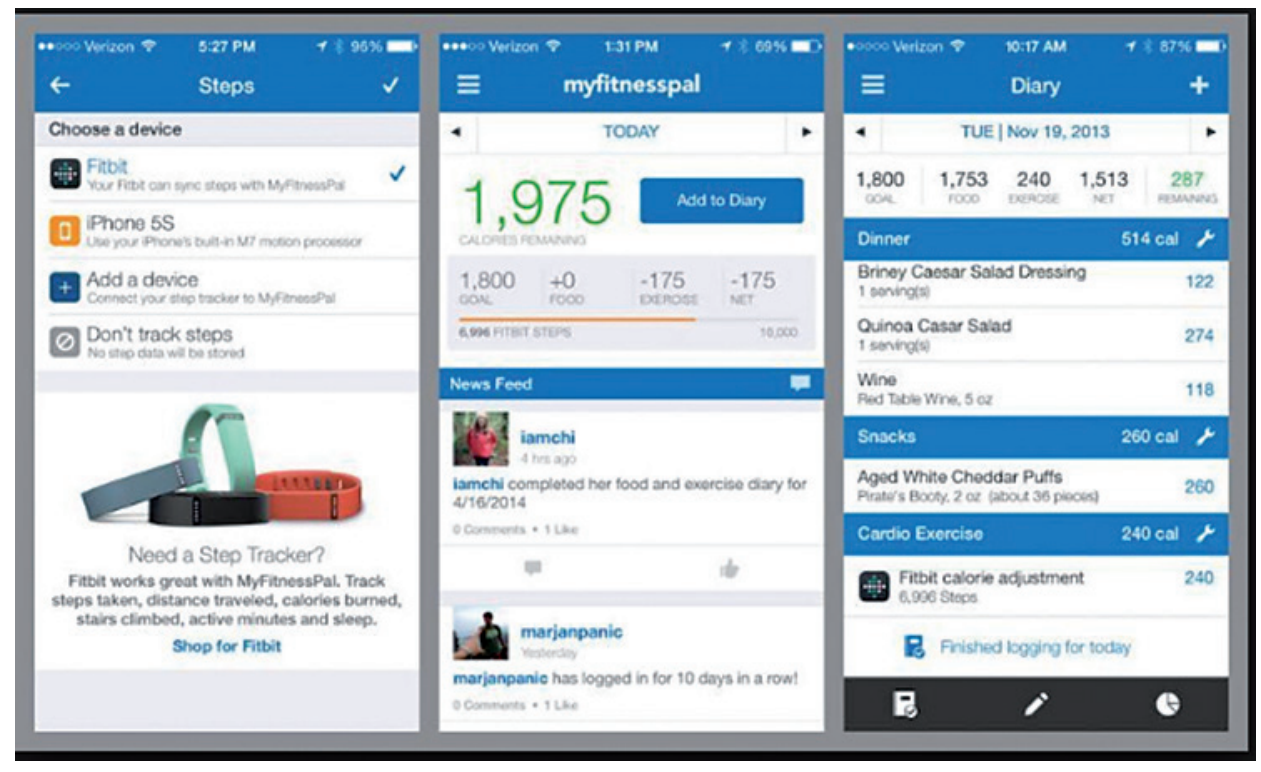

Rysunek 3. MyFitnessPal

Źródło:https://play.google.com/store/apps/details?id=com.myfitnesspal.android\&hl=pl.

${ }^{6}$ MyFitnessPal, https://play.google.com/store/apps/details?id=com.myfitnesspal.android\&hl=pl (dostęp: 17.08.2018). 
Wyniki badania wskazały:

1. zalety:

- bardzo rozbudowana baza produktów,

- bardzo szybkie i intuicyjne, samodzielne dodawanie nowych produktów,

- możliwość połączenia się z Polarem i innymi monitorami aktywności, dzięki czemu można zmieniać ilość kalorii w zależności od tego, ile użytkownik spalił kalorii po treningu,

- monitorowanie picia wody,

— możliwość dodawania znajomych,

— prosty i intuicyjny wygląd;

2. wady:

- zaniżone automatyczne wyliczanie zapotrzebowania kalorycznego,

— brak motywatorów,

— niektóre funkcje dostępne są tylko w wersji płatnej.

\section{Kcalmar - dieta i przepisy ${ }^{7}$}

Kcalmar to przygotowany przez dietetyków serwis z planowaniem diety (rysunek 4).

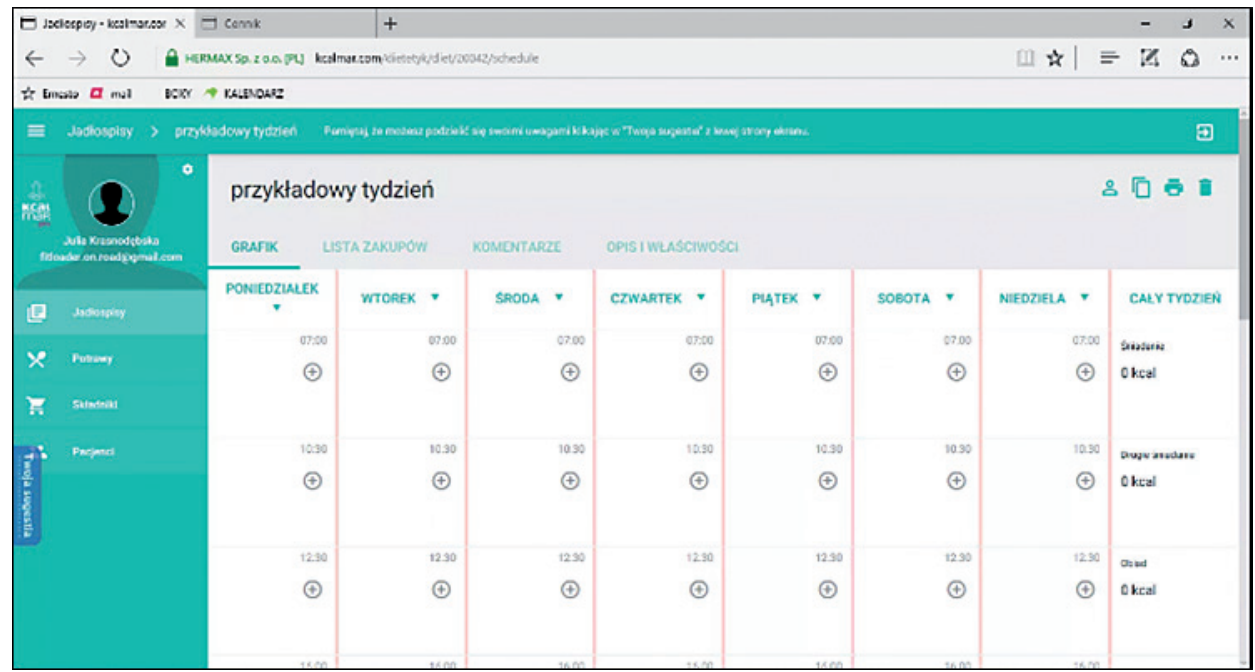

Rysunek 4. Kcalmar

Źródło: https://kcalmar.com/.

Wyniki badania wskazały:

1. zalety:

— możliwość określenia celu do osiągnięcia: zdrowe odżywianie, utrata wagi, wyrzeźbione ciało, poprawa wydolności fizycznej lub zwiększenie wagi,

— możliwość odszukania adresu dietetyka,

7 Kcalmar, https://kcalmar.com/ (dostęp: 17.08.2018). 
— wybór diety - zaproponowany zostaje gotowy program dietetyczny według kategorii „korpo”, ,zdrowie”, ,mama” (dla kobiet planujących ciążę lub propozycje zdrowej diety rodzinnej) i „sport”,

— podana jest dieta — dokładnie rozpisana na tydzień,

— prosty i intuicyjny wygląd;

2. wady:

— brak możliwości sprawdzenia kaloryczności produktów,

— brak możliwości skanowania produktów,

— aplikacja nie sprawdza kaloryczności poszczególnych produktów.

\section{Kalkulator Kalorii 8}

Kalkulator Kalorii to kolejna aplikacja mobilna działająca na zasadzie liczenia kalorii oraz dopasowywania posiłków do wybranego celu (rysunek 5).

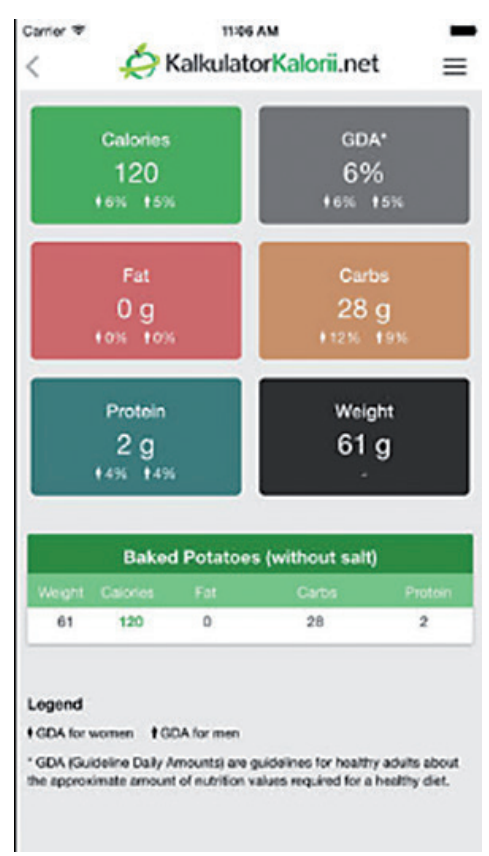

Rysunek 5. Kalkulator Kalorii

Źródło: https://kalkulatorkalorii.net/.

Wyniki badania wskazały:

1. zalety:

— w wersji podstawowej jest kalkulator kalorii (ponad 5000 produktów), kalkulator przemiany materii oraz kalkulator BMI,

— aplikacja służy doraźnemu sprawdzeniu, ile kalorii zjeść dziennie,

— zawiera proste dietetyczne przepisy;

${ }^{8}$ Kalkulator Kalorii, https://kalkulatorkalorii.net/ (dostęp: 17.08.2018). 
2. wady:

— dopiero w wersji płatnej jest dostęp do możliwości rejestrowania zjedzonych posiłków, zaplanowania jadłospisu, planowania treningów i obliczania indywidualnych limitów kalorycznych,

— nie ma połączenia z aplikacjami sportowymi, nie ma rozpisanego celu ani osiąganych etapów na drodze do celu przy uprawianiu sportów.

\subsection{Wnioski końcowe z badania}

Badanie wykazało, że wobec aplikacji mobilnych typu fit badana grupa miała konkretne oczekiwania.

1. Jaka jest ocena i oczekiwania użytkowników wobec aplikacji mobilnych fit?

Przede wszystkim możliwość skanowania produktów, wprowadzania danych oraz połączenia $\mathrm{z}$ aplikacjami sportowymi oraz wagą mierzącą stan składu organizmu. Osoby badające oczekiwały od aplikacji mobilnej także możliwości ustalenia celu oraz działań mobilizujących do cyklicznego osiągania celu, na przykład poprzez alerty żywnościowe, przypominanie o piciu wody i uprawianiu sportu. Najwyżej zostały ocenione aplikacje FatSecret oraz Fitatu.

2. Czy planowanie posiłków oraz dieta pod kontrolą technologii to trend, czy konieczność?

Badane osoby stwierdziły, że jest to konieczność. Podczas użytkowania aplikacji „odkrywały”, jak dużo kalorii zjadały wcześniej „przypadkowo” oraz jak wiele produktów uznawały za mało kaloryczne, a w rzeczywistości były one „bombami kalorycznymi”.

Badani uznali, ze jest to konieczność, gdyż pozwala to na świadome kupowanie produktów, planowanie posiłków z zapewnieniem organizmowi odpowiednich wartości odżywczych i nauczenie się zdrowych nawyków żywnościowych.

\section{Podsumowanie}

Mobilnych aplikacji typu fit jest na rynku bardzo dużo i mają one coraz więcej możliwości. Każda osoba posiadająca smartfona po zainstalowaniu aplikacji może na bieżąco kontrolować wartości odżywcze posiłków oraz całodzienny bilans przyswajanych składników. Większość aplikacji oferuje szeroki wybór produktów spożywczych oraz umożliwia dodawanie własnych pozycji. Korzystając z tego rodzaju udogodnień, należy jednak pamiętać, że aplikacja to tylko narzędzie w uczeniu się nowych nawyków żywnościowych, planowania ilości spożywanych kalorii oraz treningów. Aplikacje mobilne typu fit są pomocne w prowadzeniu zdrowego stylu życia, atrakcyjne wizualnie i funkcjonalnie. Zdaniem autorki artykułu stanowią interesujące zastosowanie dla smartfona — zamiast całymi dniami przeglądać Facebooka można technologię zastosować do tego, żeby być zdrowym. 


\section{Bibliografia}

Aplikacje sportowe, http://marketingbusiness.pl/technologie/wspolczesne-aplikacje-sportowe/hur qgey (dostęp: 17.08.2018).

Endomondo, http://www.komputerswiat.pl/poradniki/smartfony-i-tablety/aplikacje/2017/06/endomondo-sports-tracker.aspx (dostęp: 17.08.2018).

FatSecret, https://www.fatsecret.pl/ (dostep: 17.08.2018).

Fitatu, http://pl-pl.fitatu.com/ (dostęp: 17.08.2018).

Frąckiewicz E. (2006), Marketing internetowy, Warszawa.

Kalkulator Kalorii, https://kalkulatorkalorii.net/ (dostęp: 17.08.2018).

Kcalmar, https://kcalmar.com/ (dostęp: 17.08.2018).

MiFit, https://play.google.com/store/apps/details?id=com.xiaomi.hm.health\&hl=pl (dostęp: 17.08.2018).

Mureta C. (2013), APP imperium aplikacji. Niech technologia pracuje na Twój sukces, Gliwice.

MyFitnessPal, https://play.google.com/store/apps/details?id=com.myfitnesspal.android\&hl=pl (dostęp: 17.08.2018).

Pawełoszek-Korek J. (2009), Technologie mobilne w dostarczaniu wiedzy, Częstochowa.

Sznajder A. (2014), Technologie mobilne w marketingu, Warszawa. 